\title{
Kaliumin merkitys kevätviljoilla
}

\author{
Petra Manninen ${ }^{1)}$, Jouko Kleemola ${ }^{2}$, Pirjo Mäkelä ${ }^{1)}$ \\ 1) Helsingin Yliopisto, Soveltavan biologian laitos, PL 27, 00014 Helsingin Yliopisto \\ petra.manninen@helsinki.fi,pirjo.makela@helsinki.fi \\ 2) Kemira Grow-How Oyj, Espoon Tutkimuskeskus, PL 44, 02271 Espoo \\ jouko.kleemola@kemira-growhow.com
}

\section{Tiivistelmä}

Ravinteiden tehokas hyväksikäyttö on kestävän kasvintuotannon kannalta keskeistä. Lähes kaikki tutkimus on keskittynyt kuitenkin typpeen ja fosforiin lähinnä näiden aiheuttamien ympäristöhaittojen vuoksi. Sadontuoton ja erityisesti laadun kannalta kalium ja erityisesti kalium:kalsium-suhde ovat tärkeitä tekijöitä. Nykyiset käytössä olevat lannoitussuositukset perustuvat kaliumin osalta vanhoihin selvityksiin, joissa ei ole kiinnitetty niinkään huomiota kaliumin vaan typen ja fosforin tarpeeseen. Eri genotyyppien välillä tiedetään esiintyvän suurta vaihtelua kaliumin hyväksikäytössä, joten ympäristönäkökannan lisäksi voitaisiin parantaa myös viljelyn kannattavuutta tarkennettaessa kasvuston kaliumin tarve. Teollisuus puolestaan tarvitsee korkealaatuista viljaa raaka-aineeksi. Tähän voidaan pyrkiä sekä viljelyteknisin että jalostuksellisen toimin, huomioimalla modernien viljalajikkeiden erityistarpeet $\mathrm{mm}$. ravinteiden käytön suhteen ja käyttämällä elinvoimaista siementä. Elinvoimainen siemen takaa tasaisen alkuunlähdön orastumisvaiheessa parantaen välillisesti sadon laatua. Kalium saattaa puolestaan lisätä siemenen elinvoimaa.

Tutkimuksen tarkoituksena oli selvittää kaliumin ja kalium:kalsium-suhteen merkitystä ohran kasvustorakenteeseen, jyväntäyttymiseen ja siemenen elinvoimaan päämääränä laadullisesti ja määrällisesti tasaisen sadon, suuren jyväkoon ja elinvoimaisen siemenmateriaalin saavuttaminen. Koe järjestettiin kasvihuoneella Helsingin yliopiston soveltavan biologian laitoksella astiakokeena. Ohra kylvettiin lannoittamattomaan, kalkittuun kasvuturpeeseen 7.5 L altakasteluastioihin. Astioihin lisättiin 50, 100, 200 ja 800 $\mathrm{mg} \mathrm{K} \mathrm{L}{ }^{-1}$. Peruslannoituksena annettiin lisäksi $250 \mathrm{mg} \mathrm{N} \mathrm{L}^{-1}, 50 \mathrm{mg} \mathrm{P} \mathrm{L}^{-1}$ ja $33 \mathrm{mg} \mathrm{Ca} \mathrm{L}^{-1}$. Kalsiumia annettiin joko peruslannoituksen $33 \mathrm{mg} \mathrm{L}^{-1}$ tai suurempi lannoitus, jolloin Ca lisättiin lisäksi viisi kertaa $\mathrm{K}$ lannoitusta vastaava määrä. Koe oli täydellisesti satunnaistettu ja siinä oli kuusi toistoa. Kasveista havainnoitiin itävyys, sivuversoista ja pääversoista biomassan ja lehtialan muodostus, lehtialan kesto, tautien esiintyminen, korrenseinämän paksuus ja kasvin pituus, jyväpaino- ja lukumäärä sekä vesisuhteet, yhteyttäminen ja klorofyllipitoisuus.

Kaliumpitoisuuden kohotessa kasvien lehtiala kasvoi ja lehtialan kesto piteni. Kasvien biomassa oli jopa kolme kertaa suurempi korkeissa kaliumpitoisuuksissa kuin matalissa. Korrenseinämän paksuus kasvoi kaliumpitoisuuden kasvaessa ja silmämääräisten havaintojen perusteella kasvusto oli tukevampi korkeissa kaliumpitoisuuksissa. Tähkä- ja jyväpaino oli lähes puolet korkeampi korkeissa kaliumpitoisuuksissa kuin matalissa. Sienitauteja esiintyi eniten matalissa kaliumpitoisuuksissa. Kalium ei vaikuttanut kasvuston kehittymisrytmiin.

Kaliumia esiintyy viljoilla eniten korsissa, koska se on solujen rakennusaine. Kaliumia tarvitaan myös solun aineenvaihdunnassa kontrolloimaan ionitasapainoa entsyymiaktiivisuuden ylläpitämiseksi. Kalium toimii joidenkin entsymaattisten reaktioiden ko-faktorina. Kalium säätelee myös ilmarakojen toimintaa, jolloin se vaikuttaa välillisesti yhteyttämiseen. Lisäksi kaliumilla on tärkeä rooli sokerien kuljetuksessa korsista ja lehdistä jyviin. Täten kaliumilla on ensisijainen rooli jyväntäyttymisessä ja jyväkoon säätelyssä. Havaittu jyväpainon nousu onkin selvä osoitus kaliumin roolista kasvustorakenteen ja sadon osatekijänä. Kaliumlisäyksellä saavutettu korkeampi jyväpaino saattaa selittyä suuremman biomassan ja vähäisemmän tautien esiintymisen kautta yhteyttämistuotteiden saatavuuden paranemisella.

Asiasanat: Biomassa, kalium, kalsium, lehtiala, sadonmuodostus, Hordeum vulgare 


\section{Johdanto}

Kaliumilla $\left(\mathrm{K}^{+}\right)$on useita tärkeitä vaikutuksia kasvin kasvuun ja kehitykseen. Kalium on kaikkein yleisin kationi solulimassa. Se on hyvin liikkuva ravinne sekä maassa että kasvissa. Kalium ei ole kasvin rakennusaine vaan se on kymmenien entsyymien aktivaattori solujen aineenvaihdunnassa. Kaliumia kasvit ottavat K+-kationina ja se on kaikista yleisin kationi solulimassa. Kalium voi muodostaa jopa $10 \%$ kasvin koko kuivapainosta (Véry \& Sentenac 2003). Kalsium $\left(\mathrm{Ca}^{2+}\right)$ puolestaan vahvistaa solukkorakennetta, koska soluseinämät antavat kasville niiden rakenteellisen lujuuden. Kalsiumilla on keskeinen rooli myös juurten ja uusien versojen kasvussa. Kalsiumia kasvissa on yleensä noin 0,1-1\% (White 2001).

Kasvit tarvitsevat kaliumia lähes yhtä paljon kuin typpeä. Solulimassa kaliumin tärkein tehtävä on solunesteen osmoottisen potentiaalin säätely, jonka välityksellä kalium vaikuttaa kasvin vesitalouteen. Kalium vaikuttaa ilmarakojen sulkeutumiseen ja avautumiseen sekä kasvin kuivuuden- ja kylmänkestävyyteen. Kaliumia tarvitaan myös esimerkiksi mitokondrioiden ja monien entsyymien toimintaan erityisesti yhteyttämisessä ja hengityksessä (Kronzucker \& Szczerba 2003). Kasvin solunesteen pH on kaliumin vaikutuksesta yleensä 7-8, mikä on paras useiden entsyymien toiminnalle (Véry \& Sentenac 2003).

Kaliumilla on keskeinen rooli metaboliassa, jonka seurauksena yhteyttämistuotteita kuljetetaan lähteiden ja kohteiden välillä. Juurten ottamat ravinteet kuljetetaan puuosaa pitkin versoon ja yhteyttämistuotteet nilan kautta juuriin. Kaliumin puute voi vaikuttaa yhteyttämistuotteiden siirtoon lähteestä kohteeseen joko suoraan nilan täytön kautta sekä kuljetukseen tai epäsuoraan alentamalla kohteen kykyä vastaanottaa yhteyttämistuotteita. Nilassa helposti liikkuvat ravinteet, kuten kalium ja typpi, kulkeutuvat uudelleen versosta juuriin yhdessä yhteytetyn hiilen kanssa. Lisäksi ravinteiden kierrättäminen versosta juuriin voi pitää yllä kationi-anioni tasapainoa versossa, lisätä virtauksen määrää nilassa tai puuosassa sekä toimia signaalina versosta juuriin välittäen signaalin ravinteiden tarpeesta ja säädellen näin ravinteiden ottoa ja puuosan täyttöä (Marschner ym. 1996).

Nilassa olevan nesteen kaliumpitoisuudet vaihtelevat yleensä välillä 50-150 mol m${ }^{-3}$ (Marschner ym. 1996). Kalium onkin vallitseva epäorgaaninen ioni nilan siiviläelementin nesteessä (Gould ym. 2004). Korkea kaliumpitoisuus siiviläputkissa vaikuttaa myös huomattavasti virtausnopeuteen ja edistää täten yhteyttämistuotteiden kuljetusta lähteestä kohteeseen (Marschner ym. 1996). Nopea kasvin kasvu ja kehittyminen vaativat suurta K+ kuljetusvirtaa kasvaviin solukoihin (Pilot ym. 2003). Kasvisolukon täytyy pitää yllä riittävää $\mathrm{K}^{+}$pitoisuutta toimiakseen optimaalisesti. Kasveilla, joilla on runsaasti saatavilla kaliumia, sen otto ja kasvu ovat tasapainossa (White 1997).

Osmoottisena tekijänä kaliumin uskotaan osittain pitävän yllä siiviläelementin hydrostaattisen paineen ja täten säätelevän nesteen virtausta lähteestä kohteeseen. Alhaisessa kaliumpitoisuudessa kasvatetuilla ohrilla siiviläelementtien kaliumpitoisuus sekä hydrostaattinen paine on alhaisempi kuin korkeammassa kaliumpitoisuudessa kasvatetuilla ohrilla. Paine kasvin kohdesoluissa säätelee myös nesteen kulkeutumista. Kohdesolujen hydrostaattinen paine voi aiheutua solunesteen osmoottisen paineen muutoksista (Gould ym. 2004).

Kalium edistää soluseinien paksuuskasvua lisäämällä hiilihydraattien synteesiin. Kaliumin puutteessa viljojen korsi heikkenee. Tämä johtuu siitä, että hiilihydraatteja ei siirretä riittävästi solunseinämäaiheiden muodostamiseksi. Heikko korsi puolestaan altistaa kasvuston lakoutumiselle sekä heikentää kasvien vastustuskykyä sienitauteja vastaan (Marschner ym. 1996).

Kokeen tavoitteena oli selvittää eri kaliumlannoitustasojen vaikutus ohran kasvuun ja kehitykseen sekä korren soluseinien rakenteeseen ja paksuuteen. Lisäksi tutkittiin, miten kaliumlannoitus vaikuttaa kasvustorakenteeseen, kuten lehtialan ja biomassan muodostukseen, jyvien täyttymiseen ja lukumäärään ja sitä kautta sadonmuodostukseen. Kokeessa oli mukana myös kalsiumkäsittely kalium-kalsium suhteen merkityksen selvittämiseksi kasvustorakenteen ja sadonmuodostuksen kannalta. 


\section{Aineisto ja menetelmät}

Koe suoritettiin täydellisesti satunnaistettuna astiakokeena kasvihuoneessa Helsingin Yliopiston soveltavan biologian laitoksella ajalla 4.5.2005 - 12.8.2005. Kasvimateriaalina oli kaksitahoinen ohra (Hordeum vulgare L. cv. Scarlett). Kasvualustana käytettiin lannoittamatonta, kalkittua kasvuturvetta. Altakasteluastioiden tilavuus oli 7.5 litraa. Kasvualustaan lisättiin astioittain lannoitteet (taulukko 1) ennen kylvöä. Kokeessa oli neljä eri kaliumlannoitustasoa 50, 100, 200 ja $800 \mathrm{mg} \mathrm{K} \mathrm{L}^{-1}$ ja kalsiumkäsittelytasot, vähän kalsiumia sisältävä taso $33 \mathrm{mg} \mathrm{L}^{-1}$ sekä paljon kalsiumia sisältävä taso, jolloin kalsiumlannoitus oli viisinkertainen kaliumlannoitukseen verrattuna. Kaikkiin astioihin lisättiin myös $250 \mathrm{mg} \mathrm{N} \mathrm{L}{ }^{-1}$ ja $150 \mathrm{mg} \mathrm{P} \mathrm{L}^{-1}$. Erilaisia lannoituskäsittely-yhdistelmiä oli kahdeksan (taulukko 1). Kokeessa oli kuusi toistoa.

Taulukko 1. Kokeessa käytetyt kalium- ja kalsium-lannoitustasot.

\begin{tabular}{ccc}
\hline & \multicolumn{2}{c}{$\mathrm{mg} \mathrm{L}^{-1}$} \\
\cline { 2 - 3 } Koejäsen & Kalium & Kalsium \\
\hline 1 & 50 & 33,3 \\
2 & 50 & 283 \\
3 & 100 & 33,3 \\
4 & 100 & 533 \\
5 & 200 & 33,3 \\
6 & 200 & 1033,3 \\
7 & 800 & 33,3 \\
8 & 800 & 4033,3 \\
\hline
\end{tabular}

Peittaamattomat ohran siemenet kylvettiin astioihin 4.5.2005 (30 kpl astiaa kohden) ja harvennettiin orastumisen jälkeen siten, että kuhunkin astiaan jäi 20 kasvia. Astioita kierrätettiin kasvihuoneessa viikon välein reunavaikutuksen minimoimiseksi. Kasvihuoneolosuhteet vakioitiin PRIVA-säätöautomatiikalla. Päivän pituus oli $16 \mathrm{~h}$, PPFD noin $400 \mu \mathrm{mol} \mathrm{m} \mathrm{m}^{-2}$ ja lämpötila oli säädetty noin $21^{\circ} \mathrm{C}$.

Kasveista havainnointiin itävyys laskemalla itäneiden kasvien määrä itämisen jälkeen kolmena peräkkäisenä päivänä. Näytteet biomassan ja lehtialan muodostumisen seuraamiseksi kerättiin ensimmäisen kerran 22 päivää kylvön jälkeen kasvien ollessa 4-lehtiasteella. Näytteiden keräystä jatkettiin kahden viikon välein. Pää- sekä sivuversojen lehtiala määritettiin LI-3000-A lehtialamittarilla (LI-COR Inc. USA). Eri kasviosien tuorepaino punnittiin heti näytteiden keräämisen jälkeen. Näytteitä kuivattiin uunissa 80 ${ }^{\circ} \mathrm{C}$ :ssa kahden vuorokauden ajan, jonka jälkeen niiden kuivapaino punnittiin. Tämän lisäksi mitattiin kasviyksilöiden pituus, laskettiin pää- ja sivuversojen lehtien sekä kuolleiden lehtien lukumäärä, sivuversojen lukumäärä ja pääverson korren seinämän paksuus. Pölyttymisen jälkeen tähkänäytteitä kerättiin viikon välein. Tähkät punnittiin, ne jaettiin jyviin ja akanoihin, jotka punnittiin. Tämän lisäksi jyvien lukumäärä laskettiin.

Kasveista mitattiin vesipotentiaali vesipotentiaalimittarilla (Model 3000 Plants Water Status Console, Soil Moisture Equipment Co., USA) ylimmästä kasvavasta lehdestä. Samasta lehdestä mitattiin osmoottinen potentiaali osmometrillä (Micro-osmometer, Model 3MO, USA). Fotosynteesi mitattiin kerran kokeen aikana LI-6400 Portable Photosynthesis System-mittarilla (LI-COR Inc., USA). Klorofyllipitoisuus mitattiin SPAD:lla (Chlorophyll meter SPAD-502). Saadut arvot suhteutettiin spektrofotometrillä (SHIMADZU UV-160A, Japani) mitattuihin asetoniuuton tuloksiin. Tuleentuneesta kasvustosta kerätyistä näytteistä määritettiin ravinnepitoisuudet XRF- analyysillä Kemira Grow-How:n tutkimusasemalla Espoossa.

Kasvitaudit havainnointiin silmämääräisesti sekä määrittämällä esiintyvät kasvitaudit. Korren solurakenne ja solujen koko määritetään mikroskooppisesti leikkeistä.

Tulokset analysoitiin varianssianalyysillä (SPSS 12.0, faktorianalyysi), jolloin voitiin verrata kaliumin ja kalsiumin vaikutuksien lisäksi niiden yhdysvaikutusta vastemuuttujiin. 


\section{Tulokset ja tulosten tarkastelu}

Kalium lisäsi merkitsevästi ohran lehtialaa. Pääversojen lehtialan lopullinen suuruus oli kuitenkin melko samanlainen kolmella ylimmällä kaliumlannoitustasolla. Pääversojen lehtialan kesto (LAD) oli sen sijaan huomattavasti pidempi kaliumlannoituksen lisääntyessä (Kuva 1A). Tähän on voinut vaikuttaa mahdollisesti kasvien parempi vastustuskyky sienitauteja vastaan. Kalium lisäsi myös sivuversojen lehtialaa. Ero oli merkitsevä myös kahden korkeimman kaliumtason välillä. Kalium lisäsi myös sivuversojen lehtialan kestoa (Kuva 1B). Korkeimmalla kaliumlannoitustasolla sivuverson lehtialan maksimi ajoittui myöhemmäksi, mikä osaltaan on voinut vaikuttaa lehtialan kestoon. Alhaisimmalla kaliumlannoitustasolla kasvit alkoivat muodostaa sivuversoja kasvukauden loppupuolella. Pääversojen spesifisessä lehtialassa (SLA) oli merkitseviä eroja kasvun loppuvaiheissa (Kuva 1D). Sivuversojen spesifisessä lehtialassa ei esiintynyt eroja kaliumlannoitustasojen välillä.
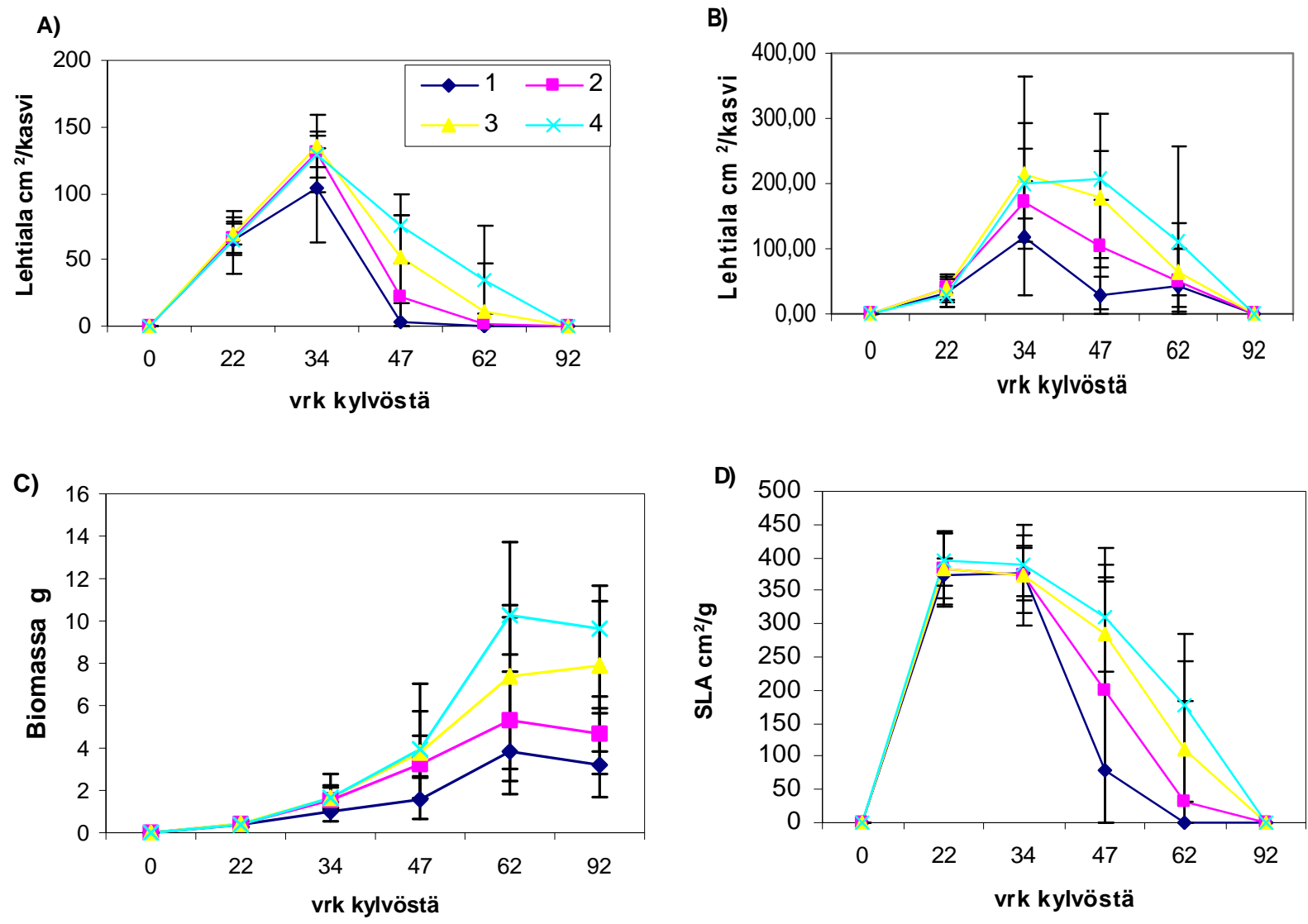

Kuva 1. Kaliumin vaikutus A) Pääverson lehtialan muodostumiseen, B) Sivuversojen lehtialan muodostumiseen, C) kokonaisbiomassan muodostumiseen ja D) pääversojen spesifinen lehtiala (SLA). Kuvissa on esitetty keskiarvot $(\mathrm{n}=6)$ sekä hajontavälit. 
Kaliumlannoitus lisäsi merkitsevästi kokonaisbiomassan muodostusta kasvukauden aikana (Kuva 1C). Korkeampien kaliumlannoitusten suurempaa biomassaa voidaan selittää lisääntyneellä lehtialalla, lehtialan kestolla, korkeammalla nettofotosynteesillä sekä kasvitautien esiintymisen vähyydellä. Lisäksi Pilot ym. (2003) ovat havainneet nopean kasvuvaiheen edellyttävän korkeita kaliumpitoisuuksia kasveissa.

Kaliumlannoitus lisäsi nettofotosynteesiä (Kuva 2B) Kronzuckerin ja Szcerban (2003) johtopäätösten mukaisesti. Lisäksi kaliumin ja kalsiumin välillä oli yhdysvaikutus. Korkein nettofotosynteesi oli kasveissa, jotka olivat saaneet paljon kaliumia.

Kalium vaikutti merkitsevästi myös korren seinämän paksuuteen (Kuva 2A) samoin kuin Marschner ym. (1996) ovat todenneet. Tämä ilmeni kasveissa myös silmämääräisesti, sillä alhaisemmilla Klannoitustasoilla kasvit olivat lakoutumisherkkiä.

Kaliumlannoituksen kohotessa ohran jyväpaino ja tuhannen jyvän paino kohosivat (Kuva 2C). Tähän on vaikuttanut kaliumlannoituksen lisääntymisen myötä muodostunut suurempi biomassa sekä lehtiala ja sen kesto. Kalium on saattanut vaikuttaa myös yhteyttämistuotteiden kohdentamiseen ja siirtoon, mikä saattaa osaltaan selittää suurempaa jyväpainoa (Marschner ym. 1996). Kalium lisäsi myös jyvien lukumäärää tähkässä (Kuva 2D). Korkea kaliumlannoituksen taso johti myös korkeaan sivuversojen jyvien lukumäärään ja painoon. Alhaisilla lannoitustasoilla sivuversot jäivät pieniksi.

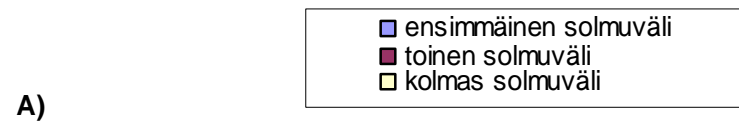

A)

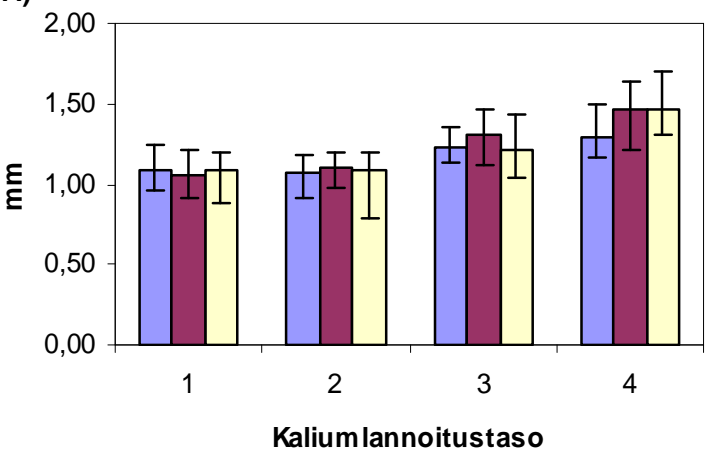

C)

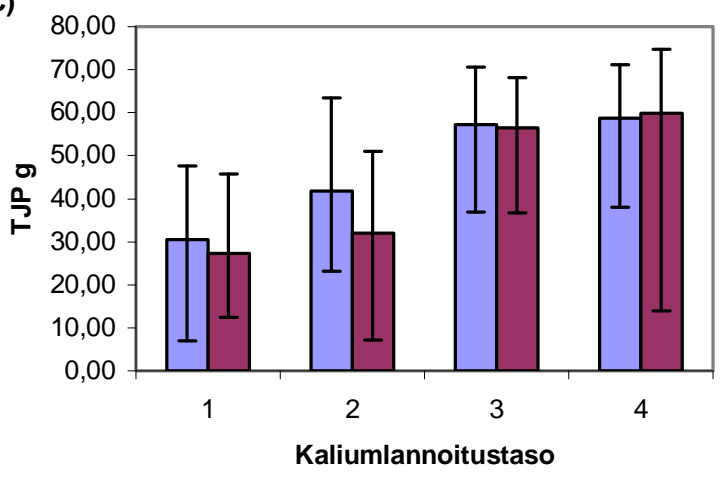

$\square$ Vähän Ca $\square$ Paljon Ca

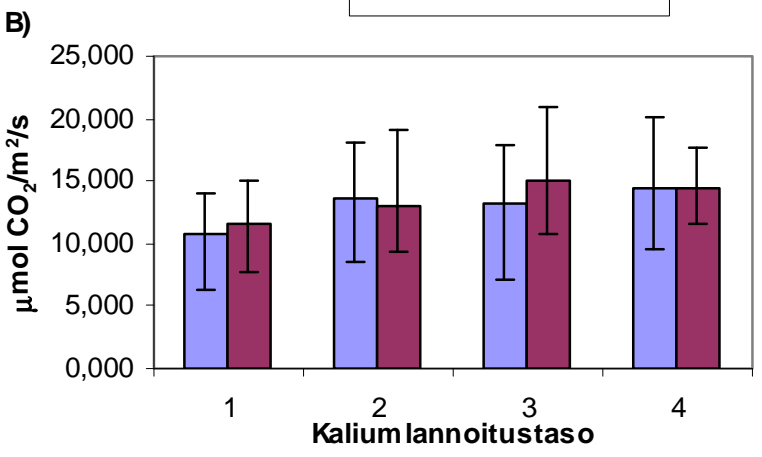

D)

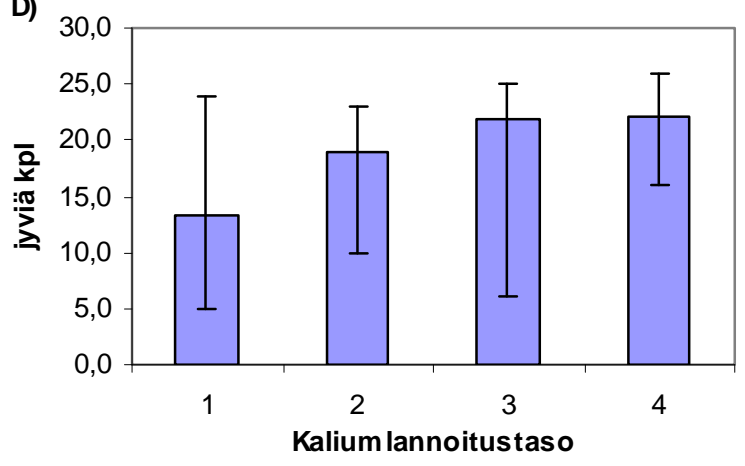

Kuva 2. A) Korren seinämän paksuus eri kaliumlannoitustasoissa 62 vrk kylvön jälkeen, B) K- ja Ca-lannoituksen vaikutus ohran yhteyttämiseen, C) K- ja Ca-lannoituksen vaikutus ohran tuhannen jyvän painoon (TJP) ja D) Klannoituksen vaikutus ohran jyvälukumäärään. Kuvissa on esitetty keskiarvot $(n=6)$ sekä vaihteluväli. 
Kaliumlannoitus lisäsi kaliumin määrää sekä lehdissä että korsissa (Taulukko 2). Kalsiumin määrä kasvissa pieneni kaliumlannoituksen lisääntyessä, joten kalium vaikutti kalsiumin määrään kasvissa. Kaliumia oli lehdissä ja korsissa lähes yhtä paljon. Sen sijaan kalsiumin osuus oli suurempi lehdissä. White (1997) on todennut myös ravinteiden oton ja kasvun olevan tasapainossa, mikäli kasveilla on runsaasti kaliumia saatavilla.

Taulukko 2. Kaliumin ja kalsiumin osuus (\%) kasvin kuivapainosta eri kaliumlannoitustasoilla sekä keskihajonta.

\begin{tabular}{lrrrrr}
\hline & & \multicolumn{2}{c}{ Korsi } & & \multicolumn{2}{c}{ Lehdet } \\
\cline { 3 - 5 } mg L L $^{-1}$ & $\mathrm{~K}, \%$ & $\mathrm{Ca}, \%$ & $\mathrm{~K}, \%$ & $\mathrm{Ca}, \%$ \\
\hline 50 & $0,6 \pm 0,31$ & $1,0 \pm 0,33$ & $0,6 \pm 0,28$ & $3,1 \pm 0,34$ \\
100 & $0,8 \pm 0,44$ & $0,7 \pm 0,19$ & $0,9 \pm 0,22$ & $3.0 \pm 0,35$ \\
200 & $1,7 \pm 0,60$ & $0,4 \pm 0,18$ & $1,7 \pm 0,34$ & $2,6 \pm 0,44$ \\
800 & $4,4 \pm 0,24$ & $0,3 \pm 0,11$ & $4,1 \pm 0,38$ & $1,8 \pm 0,31$ \\
\hline
\end{tabular}

\section{Johtopäätökset}

Kaliumin lisääminen kasvualustaan vaikutti selvästi ohran sadonmuodostukseen. Kaliumlannoituksen lisäyksen myötä muodostunut suurempi biomassa ja lehtiala mahdollistavat tehokkaan yhteyttämisen. Pidentynyt lehtialan kesto pidensi jyvän täyttymisperiodia. Tehokas yhteyttäminen ja lehtialan kesto johtivat suurempaan jyväkokoon korjeilla kaliumlannoitustasoilla kuin matalilla. Kaksi alinta kaliumlannoitustasoa olivat selvästi kahta korkeinta tasoa heikompia kaikkien mitattujen ominaisuuksien suhteen. Juuriston kehityksellä kasvun alkuun lähdössä on huomattava rooli kasvuston muodostumisessa veden ja ravinteiden oton turvaajana varsinkin Suomen kevään kuivissa oloissa. Kaliumin vaikutusta jyvän itämiseen ja kasvuun lähtöön kannattaisikin selvittää tarkemmin.

\section{Kirjallisuus}

Gould, N., Thorpe, M.R., Minchin, P.E.H., Pritchard, J. \& White, P.J. 2004. Solute is imported to elongating root cells of barley as a pressure driven-flow of solution. Funct. Plant Biol. 31: 391-397.

Kronzucker, H.J \& Szczerba, M.W. 2003. Cytosolic potassium homeostasis revisited: ${ }^{42} \mathrm{~K}$-tracer analysis in Hordeum vulgare L. reveals set-point variations in [K+]. Planta 217:540-546.

Marschner, H., Kirkby, E.A \&Cakmak, I. 1996. Effect of mineral nutritional status on shoot-root partitioning of photoassimilates and cycling of mineral nutrients. J. Exp. Bot. 47: 2063-2073.

Pilot, G., Gaymard, F., Moulinen, K., Chérel, I. \&Sentenac, H. 2003. Regulated expression of Arabidopsis Shaker K+ channel genes involved in K + uptake and distribution in the plant. Plant Mol. Biol. 51: 773-787.

Véry, A.A \&Sentenac, H. 2003. Molecular mechanisms and regulation of K+ transport in higher plants. Annu. Rev. Plant Biol. 54:573-603.

Walker D.J., Black, C.R. \&Miller, A.J. 1998. The role of cytosolic potassium and pH in the growth of barley roots. Plant Physiol. 118:957-964.

White, P.J. 1997. The regulation K influx into roots of rye (Secale cereale L.) seedling by negative feedback via the K+ flux from shoot to root in the phloem. J. Exp. Bot. 48: 2063-2073.

White, P.J. 2001. The pathways of calcium movement to the xylem. J. Exp. Bot. 52: 891-899. 